\title{
An analytical study for basic skills and it's effectiveness on Matches results of volleyball at Beijing and London Olympic Games \\ *D / Khaled A. elbattawy \\ Abstract:
}

The purpose of the study was to determine the effect of a team's level on the performance of skills (serve, reception, spike, block and dig) in high level volleyball. Thirty-eight mens matches of London Olympics Games 2012 and 38 mens matches of the Olympics Games of Beijing 2008 were purchased from the international volleyball Federation and analyzed. The performance of skills was evaluated in relation to the success and options that these skills give to one's team. The team's level was established in relation to the final classification of the team in both competitions (level 1: 1st - 4th; level 2: 5th - 8th; \& level 3: 9th - 12th). Six observers participated in the study. In London Olympics Games 2012 the results show a high significant difference between teams' levels for the skills of spiking and setting. The dig and reception are the skills that differentiates the teams of level 1 with the teams of level 2. In Beijing Olympics Games2008, we found a significant difference in the performance of the set in the teams of level 1. An increase in success of reception, spike, reception and dig in relation to the level of the team is observed.

Key words: volleyball, performance, skills.

\section{Introduction}

Volleyball is a very popular sport worldwide, with millions of people participating and playing a game at least once a week (Kenny, \& Gregory, 2006). Volleyball is differentiated from the rest of team sports, because although it is a sport with discrete skills, the game has a cyclical and sequential pattern (Beal, 1989). It is possible to find a sequence of the actions in the game (graph 1).

Teacher in Games department - faculty of physical education - Monofya University - Egypt

Assiut Journal For Sport Science Arts 


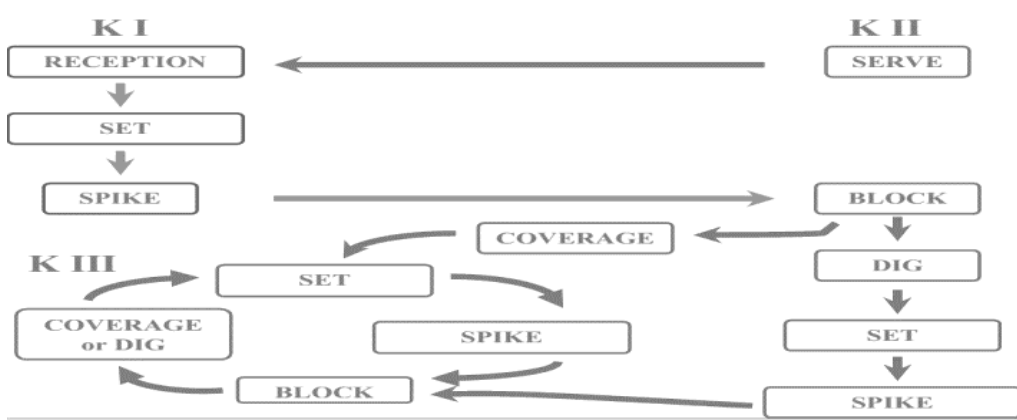

Regardless of the rule changes, the game is constructed by a series of individual skills that are directly related to the team's performance and proficiency. In comparative evaluations of the game's skills.

Performance analysis is a way to understand the factors explaining success in elitelevel sports. It gives coaches knowledge of the sport so they can think of ways to develop playing and training (Bergeles, 2009). Performance analysis has been recently utilized in different levels of volleyball in many studies (Bergeles, 2009 Ismail, 2003).

In fact that the tendencies are still prevalent in high-level volleyball, the rally point system compelled both players and trainers to focus

their attention on avoiding errors that would reward the opponent with an easy point. Thus, many teams continue to strive toward perfect execution of the basic skills. (Laios, 2004)

A volleyball match consists of different volleyball basic skill executions, which are serve, reception, set, Spike, block, and Gig. There is technical variability in the execution of these basic skills. (Lobietti 2006) . Previous studies have analyzed player and team performance in several top-level women's and men's volleyball tournaments. The efficiency of different skills has been observed in relation to winning a match.

Most of these studies have considered the differences between winning or losing a 
game, but, some Studies, they do not consider the classification of teams in the competitions. The fact of not differentiating team levels can provoke that some aspects of the game compensate between them. Also, knowing the differences between levels can let the coach clearly establish their objectives to try to achieve the next level. The purpose of this paper was to study the relationship between team's level and skill performance (serve, reception, spike, block and dig) in high level volleyball and to establish references for coaches to design and control practices and competitions.

\section{METHOD}

The total number of
games videotaped and analyzed were 76 matches, A total of (31535) Repetitions from 38 mens matches of the London Olympics Games 2012 and (35944) Repetitions from 38 mens matches of the Beijing Olympics Games 2008 in was analyzed in this descriptive preexperimental study. The observation instrument was a category system. The variables registered were spike performance, block performance, serve performance, dig performance Set performance, and reception performance, team level. Team level was established in relation to the final classification of the team in the competition: level 1 , classified between 1st - 4th; level 2, classified between 5th - 8th; and level 3, classified between 9th - 12th. Skill performance was evaluated in relation to the success and options that the actions gave to our team and the opponent's team. We utilized the statistic system of the Fédération Internationale de Volleyball (FIVB). Diaz, J. (1992, 1996). We distinguished Three levels to categorize the performance (table 1):

2 : Success Skill Performanc.

1 : Attempts Skill Performanc

0 : Error Skill Performanc

Table 1. Criteria of the Performance Level of Skill 


\begin{tabular}{c|l}
\hline \hline Spike & \\
\hline \hline 2 & $\begin{array}{l}\text { Point: the attack goes to opponent's court, the ball is unplayable } \\
\text { after block, or opponent makes an error in blocking }\end{array}$ \\
\hline 1 & $\begin{array}{l}\text { Good attack: opponent's block or dig is weak or Easy attack: } \\
\text { opponent's block or dig is good }\end{array}$ \\
\hline 0 & Error: attacker touches the net or the attack is unsuccessful \\
\hline Block & Point \\
\hline 2 & $\begin{array}{l}\text { Good attenuation of block: the ball is easy for own defense or } \\
\text { difficult for opponent's side or Weak attenuation of block: the ball } \\
\text { comes difficult to own defense or easy for opponent's side }\end{array}$ \\
\hline 0 & Error: net foul \\
\hline Serve: & Jump Serve, Jump Float Serve, or Overhead Float Serve \\
\hline 2 & point, ace \\
\hline 1 & $\begin{array}{l}\text { Good serve: (reception goes straight back to the serving team or } \\
\text { receiving team has no change to attack), Good serve: (opponent } \\
\text { has only limited attack options (no first tempo)) and Easy serve: } \\
\text { (opponent has maximum attack options) }\end{array}$ \\
\hline 0 & Serving error \\
\hline Dig & Perfect dig: quick attack tempo possible \\
\hline 2 & $\begin{array}{l}\text { Good dig: attacking is possible Or Weak dig: attacking is not } \\
\text { possible, }\end{array}$ \\
\hline 0 & Error or Dig goes straight back to the opponent \\
\hline Set & Good set \\
\hline 1 & Bad set: attacker cannot attack or has to attack with difficulty \\
\hline 0 & Technical error in setting or a set that ends the rally \\
\hline 2 & Perfect reception: quick attack tempo possible \\
\hline 1 & $\begin{array}{l}\text { Good reception: quick attack tempo is possible with minor risk Or } \\
\text { Weak reception: only limited attack options }\end{array}$ \\
\hline 0 & $\begin{array}{l}\text { Reception error Or Reception goes straight back to the serving } \\
\text { team or the receiving team has no change to attack }\end{array}$ \\
\hline \hline & \\
\hline Reception & \\
\hline 1 &
\end{tabular}

\section{All the matches were researcher used (20) dvd recorded by fivb, the contains 76 matches in beijing}


and london olympic games, and get the dvd from the international volleyball federation after their correspondence on the website www.fivb.org and is coordinating with the site receiving dvd shipments through (courier shipments).and analyzed by 6 observers were had exepirance in volleyball matech analysis.

\section{Statistical analysis}

The statistical analysis of the matches was made by ibm spss statistics 16 and microsoft office excel 2010 software. Statistical comparison between the two levels and comparisons between the teams level were made by nonparametric chisquare test. The level of statistical significance was determined as $\alpha=0.05$. All comparisons were made by the repetitions of skills and percentage of the distribution of sets. A performance coefficient is calculated (sum of attempts by category multiplied by value of the category and divided by total attempts)

\section{Results and discussion}

Table (3) shows the significance differences between the repetitions and significance of differences between the ratios for skills performance for the teams of level 1, 2, 3 at the london olympics games 2012, the teams of levels 1 and 2 have better performance than teams of level 3 in serve, reception, set, spike, block and dig. Teams of level 1 present better values than teams of level 2 . These differences between levels 1 and 2 with level 3 are statistically significant in the spike, set, dig and reception .

Table (2)

Statistical characterization, $\mathrm{N}=\mathbf{2 8 8}$ 


\begin{tabular}{|c|c|c|c|c|c|c|c|c|c|c|c|c|}
\hline \multirow{2}{*}{$\begin{array}{l}\text { Olymp-ic } \\
\text { games }\end{array}$} & \multirow{2}{*}{$\begin{array}{c}\text { Team of } \\
\text { Level }\end{array}$} & \multirow{2}{*}{$\begin{array}{l}\text { Teams } \\
\text { Rank }\end{array}$} & \multicolumn{2}{|c|}{ Height (m) } & \multicolumn{2}{|c|}{ Weight (kg) } & \multicolumn{2}{|c|}{ Age } & \multicolumn{2}{|c|}{$\begin{array}{c}\text { Spike } \\
\text { Jumb(m) }\end{array}$} & \multicolumn{2}{|c|}{$\begin{array}{c}\text { Block } \\
\text { Jumb(m) }\end{array}$} \\
\hline & & & $\mathbf{M}$ & S D & $\mathbf{M}$ & S D & $\mathbf{M}$ & S D & $\mathbf{M}$ & S D & $\mathbf{M}$ & S D \\
\hline \multirow{11}{*}{$\begin{array}{c}\text { London } \\
\text { Olympic } \\
\text { Games } \\
2012 \\
\mathrm{~N}=144\end{array}$} & \multirow{3}{*}{$\begin{array}{c}\text { Level } \\
1\end{array}$} & Russia & \multirow{3}{*}{1.98} & \multirow{3}{*}{0.08} & \multirow{3}{*}{91.29} & \multirow{3}{*}{8.92} & \multirow{3}{*}{28.73} & \multirow{3}{*}{4.77} & \multirow{3}{*}{3.43} & \multirow{3}{*}{13.94} & \multirow{3}{*}{3.24} & \multirow{3}{*}{13.11} \\
\hline & & Brazil & & & & & & & & & & \\
\hline & & $\begin{array}{c}\text { Italy } \\
\text { Bulgaria }\end{array}$ & & & & & & & & & & \\
\hline & \multirow{4}{*}{$\begin{array}{c}\text { Level } \\
2\end{array}$} & Argentina & \multirow{4}{*}{1.98} & \multirow{4}{*}{0.07} & \multirow{4}{*}{90.98} & \multirow{4}{*}{7.99} & \multirow{4}{*}{27.65} & \multirow{4}{*}{4.19} & \multirow{4}{*}{3.46} & \multirow{4}{*}{10.99} & \multirow{4}{*}{3.24} & \\
\hline & & Germany & & & & & & & & & & \\
\hline & & Poland & & & & & & & & & & 9.79 \\
\hline & & $\begin{array}{l}\text { United } \\
\text { States } \\
\end{array}$ & & & & & & & & & & \\
\hline & & Australia & & & & & & & & & & \\
\hline & & Serbia & & & & & & & & & & \\
\hline & 3 & $\begin{array}{c}\text { Great } \\
\text { Britain }\end{array}$ & 1.97 & 0.07 & 87.21 & 8.41 & 25.98 & 4.29 & 3.39 & 14.16 & 3.21 & 14.62 \\
\hline & & Tunisia & & & & & & & & & & \\
\hline Total & an, Std D & ation & 1.98 & 0.08 & 89.83 & 8.61 & 27.45 & 4.54 & 3.43 & 13.31 & 3.23 & 12.65 \\
\hline & & $\begin{array}{l}\text { United } \\
\text { States }\end{array}$ & & & & & & & & & & \\
\hline & Level & Brazil & 1.98 & 0.07 & 89.94 & 7.43 & 29.35 & 4.34 & 3.45 & 11.66 & 3.25 & 10.75 \\
\hline & & Russia & & & & & & & & & & \\
\hline Beijing & & Italy & & & & & & & & & & \\
\hline Olympic & & Bulgaria & & & & & & & & & & \\
\hline $\begin{array}{c}\text { Games } \\
2008\end{array}$ & $\begin{array}{c}\text { Level } \\
2\end{array}$ & $\begin{array}{l}\text { China } \\
\text { Poland }\end{array}$ & 1.97 & 0.07 & 86.85 & 7.75 & 27.15 & 4.19 & 3.46 & 1176 & 3.28 & 10.85 \\
\hline $\mathrm{N}=144$ & & Serbia & & & & & & & & & & \\
\hline & & Germany & & & & & & & & & & \\
\hline & Level & Venezuela & 107 & 0.07 & 90.04 & 7.97 & 27.79 & 436 & 3,44 & 1241 & 3,28 & 13.09 \\
\hline & 3 & $\frac{\text { Egypt }}{\text { Japan }}$ & & & & & & & & & & \\
\hline Total & an, Std D & ation & 1.97 & 0.07 & 88.94 & 11.92 & 28.09 & 4.37 & 3.45 & 11.92 & 3.27 & 11.61 \\
\hline
\end{tabular}

\section{M.. Mean}

\section{S D.. Standard Deviation}

The spike and set have a statistically higher performance in level 1 and it is this skill which differentiates the teams of level 1 with the teams of level 2 and level 3 . In volleyball, serve and Spike have a major role in winning the set. Also, it has been noted that digging is important in volleyball. digging is also relevant to a team's success and likelihood of winning.(Miskin, 2010) (Rodriguez, 2011)

Form1: Effectiveness of skill performance in different team of levels 


\section{in London and Beijing Olympic Games}

Form 2: Effectiveness of skill performance in team of level 1 in London Olympic Games

Form 4: Effectiveness of skill performance in team of level 2 in London Olympic Games

Form 6: Effectiveness of skill performance in team of level 3 in London Olympic Games Table (4) shows the Significance differences between the repetitions and significance of differences between the ratios for skills performance for the Teams of Level 1, 2, 3 at the Beijing Olympics Games 2008, the performance of the skills increase in relation to the level of the teams, so a higher performance of the skills is found in level 1 than in level 2 , and a higher performance is founded in level 1 than in level 3. But These differences between levels are statistically significant in the ratios of performance of the Success spike, Success Block, Success dig and Success Set in the teams of level 1. There are differences between levels are

Form 3: Effectiveness of skill performance in team of level 1 in Beijing Olympic Games

Form 5: Effectiveness of skill performance in team of level 2 in Beijing Olympic Games Form 7: Effectiveness of skill performance in team of level 3 in Beijing Olympic Games

statistically significant in the ratios of performance of the Error Set in the teams of level 2. Table (5) shows the Significance differences between the Repetitions and significance of differences between the ratios for skills performance for the Teams of Level 1, 2, 3 at the London Olympics Games 2012 and Beijing Olympics Games 2008, The results in London and Beijing Olympics Games confirmed previous studies which indicated that the spike is the action which is most correlated to the result of the competition but only between teams with higher level (first eight team classified in the Olympic games) and teams with lower level (classified 
ninth through twelfth). With respect to the Success Set, our results also ratify the previous studies but only with the first four classified in the Olympic Games. This result show the Set as the skill that establishes the differences in high level.

On the other hand, many studies report the significant contribution of the setter during a volleyball match, who, in most cases, is considered as the key for the team's victory (Bergeles, 1993; McGown, 1994; Stork, 1992; Zhang, 1996). Due to the fact that the setter is involved in all volleyball skills, player should

\section{Table (3)}

possess all the necessary skills to cope with difficult situations and to predict the strategy that the opponent team intends to develop.

As coaches, I also has to consider the use of these skills in the game to design our practices. Table 5 presents the percentage of use in the game of the different skills. In general, I observed similar values in the proportion of use of the different skills by levels, with variations between London and Beijing Olympics Games. More stability in the percentage by level is observed in London Olympics Games.

Significance differences between the Repetitions and significance of differences between the ratios for skills performance for the Teams of Level 1, 2, 3 at the London Olympics Games 2012

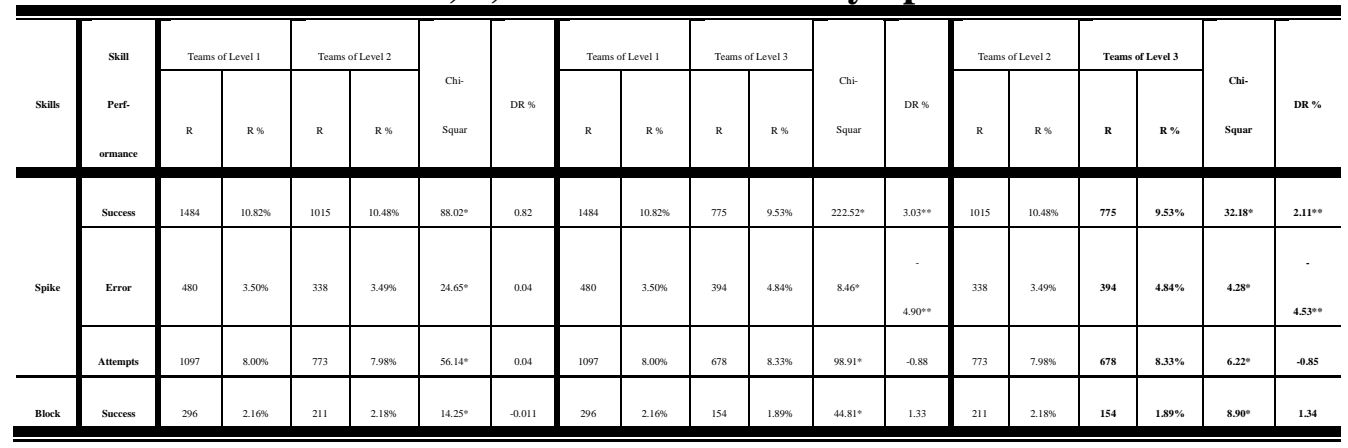

Follow Table (3) 
Significance differences between the Repetitions and significance of differences between the ratios for skills performance for the Teams of Level 1, 2, 3 at the London Olympics Games 2012



* Chi-Squar value $(0.05)=3.84$.

$* *$ significance of differences between the ratios $= \pm 1.96$.

DR \% Differences between ratios.

R Repetitions

$\mathrm{R} \%$ Ratios

Table (4) 
Significance differences between the Repetitions and significance of differences between the ratios for skills performance for the Teams of Level 1, 2, 3 at the Beijing Olympics Games 2008

\begin{tabular}{|c|c|c|c|c|c|c|c|c|c|c|c|c|c|c|c|c|c|c|c|}
\hline \multirow{2}{*}{ Skills } & \multirow{2}{*}{$\begin{array}{l}\text { Skill } \\
\text { Perfor- } \\
\text { mannee }\end{array}$} & \multicolumn{2}{|c|}{ Teans of L Level 1} & \multicolumn{2}{|c|}{ Teams of Level 2} & \multirow{2}{*}{$\begin{array}{l}\text { Chi. } \\
\text { Squar }\end{array}$} & \multirow{2}{*}{ DR \% } & \multicolumn{2}{|c|}{ Teams of L Level1 } & \multicolumn{2}{|c|}{ Teams of L.evel 3} & \multirow{2}{*}{$\begin{array}{l}\text { Chi- } \\
\text { Squar }\end{array}$} & \multirow{2}{*}{ DR \% } & \multicolumn{2}{|c|}{ Teams of L Level 2} & \multicolumn{2}{|c|}{ Teams of Level 3} & \multirow{2}{*}{$\begin{array}{l}\text { Chi- } \\
\text { Squar }\end{array}$} & \multirow{2}{*}{ DR \% } \\
\hline & & ${ }^{\mathrm{R}}$ & $\mathbf{R} \%$ & ${ }^{\mathrm{R}}$ & $\mathrm{R} \%$ & & & ${ }^{\mathrm{R}}$ & $\mathrm{R} \%$ & ${ }^{\mathrm{R}}$ & $\mathrm{R} \%$ & & & $\mathrm{R}$ & $\mathrm{R} \%$ & ${ }^{R}$ & $\mathrm{R} \%$ & & \\
\hline \multirow{3}{*}{ spike } & Suceess & 1593 & $10.31 \%$ & 1199 & $10.12 \%$ & $55.6^{\circ}$ & 0.51 & 1593 & $10.31 \%$ & 869 & $10.05 \%$ & $21291^{\circ}$ & 0.64 & 1199 & $10.12 \%$ & 869 & $10.05 \%$ & $52.66^{\circ}$ & 0.17 \\
\hline & Error & 485 & $3.14 \%$ & 407 & $3.44 \%$ & $6.82^{\circ}$ & -1.37 & 485 & $3.14 \%$ & 359 & $4.15 \%$ & ${ }^{18.81^{\circ}}$ & $4.1^{* * *}$ & ${ }_{407}$ & $3.44 \%$ & 359 & $4.15 \%$ & 3.01 & ${ }_{2,67 * *}$ \\
\hline & Attempts & 1209 & $7.22 \%$ & 979 & $8.27 \%$ & $24.18^{\circ}$ & -1.33 & 1209 & $7.82 \%$ & 648 & $7.99 \%_{6}$ & $169,48^{\circ}$ & 0.92 & 979 & $8.27 \%$ & 648 & $7.49 \%$ & $67.34^{\circ}$ & $2.02^{* *}$ \\
\hline \multirow{3}{*}{ Block } & Suceess & 362 & $2.34 \%$ & 220 & $1.86 \%$ & $34,65^{\circ}$ & $2,75^{\circ}$ & 362 & $2.34 \%$ & 130 & $1.50 \%$ & $1094^{*}$ & $4.42^{2 *}$ & 220 & $1.86 \%$ & 130 & $1.50 \%$ & $23.14^{\circ}$ & 1.93 \\
\hline & Error & 603 & $3.90 \%$ & 435 & $3.67 \%$ & $27.19 *$ & 0.98 & 603 & $3.90 \%$ & 324 & $3.75 \%$ & $8397^{\circ}$ & 0.6 & 435 & $3.67 \%$ & 324 & $3.75 \%$ & $16.23^{\circ}$ & -0.28 \\
\hline & Attempts & $m 7$ & $5.03 \%$ & 532 & $4.49 \%$ & $45.86^{\circ}$ & $206^{\circ \circ}$ & 777 & $5.03 \%$ & 371 & $4.29 \%$ & 14359\% & $2.5 \mathrm{se}^{\circ-}$ & 532 & $4.49 \%$ & 371 & $4.29 \%$ & 28. $7^{\circ}$ & 0.69 \\
\hline \multirow{3}{*}{ Serve } & Success & 142 & $0.92 \%$ & ${ }_{74}$ & $0.62 \%$ & $21.41^{\circ}$ & $2.72^{2 *}$ & 142 & $0.92 \sigma_{6}$ & 61 & $0.71 \%$ & $32.22^{\circ}$ & 1.74 & 74 & $0.62 \%$ & 61 & $0.71 \%$ & 1.25 & -0.71 \\
\hline & Error & 440 & $2.85 \%$ & 327 & $2.76 \%$ & $16.65^{\circ}$ & 0.43 & 440 & $2.85 \%$ & 294 & $3.40 \%$ & 29.9.4. & $2.39 \%$ & 327 & $2.76 \%$ & 294 & 3.4056 & 1.75 & $2.64+4$ \\
\hline & Attempts & 2326 & $15.05 \%$ & 1708 & $14,42 \%$ & $94,68^{\circ}$ & 1.46 & 2326 & $15.05 \mathrm{Fe}$ & 1154 & $13.35 \%$ & $34,71^{*}$ & 3.62 & 1708 & $14,42 \%$ & 1154 & $13.35 \%$ & $10724^{*}$ & $2.19 \%$ \\
\hline \multirow{3}{*}{ Dig } & Success & 1133 & $7.33 \%$ & 850 & $7.18 \%$ & 40,39 & 0.49 & 1133 & $7.33 \%$ & 547 & $6.33 \%$ & $2044^{*}$ & $2.94 \times$ & 850 & $7.18 \%$ & 547 & $6.33 \%$ & $65.72^{\circ}$ & $2.38^{* *}$ \\
\hline & Error & ${ }^{693}$ & $4.48 \%$ & 554 & $4.68 \%$ & 15,49 & -0.75 & ${ }_{693}$ & $4.48 \%$ & 446 & $5.16 \%$ & $5356^{\circ}$ & $2.36 \mathrm{os}$ & 554 & $4.68 \%$ & 446 & $5.16 \%$ & $11.66^{\circ}$ & -1.58 \\
\hline & Attempts & 333 & $2.16 \%$ & 267 & $2.25 \%$ & $7.26^{\circ}$ & -0.55 & 333 & $2.16 \%$ & 197 & $2.28 \%$ & $34.89 \%$ & -0.63 & 267 & $2.25 \%$ & 197 & $2.28 \%$ & $10.6^{\circ}$ & -0.11 \\
\hline \multirow{3}{*}{ Set } & Success & 1041 & $6.74 \%$ & 788 & $6.65 \%$ & $3499 \%$ & 0.28 & 1041 & 6.7456 & 514 & $5.94 \%$ & $178.6^{\circ}$ & $2, A^{* *}$ & 788 & $6.65 \%$ & 514 & 5.9456 & $57.66^{\circ}$ & $2.05 \%$ \\
\hline & Error & 16 & $0.10 \%$ & 23 & $0.19 \%$ & 1.26 & $1.96 \mathrm{mon}$ & 16 & $0.10 \%$ & 25 & $0.29 \%$ & $1.98 \%$ & 3.35 & 23 & $0.19 \%$ & 25 & $0.29 \%$ & 0.08 & .1 .39 \\
\hline & Attempts & 2113 & $13.67 \%$ & 1677 & $14.16 \%$ & $50.16^{\circ}$ & -1.14 & 2113 & $13.67 \%$ & 1294 & $1496 \%$ & ${ }_{19688^{\circ}}$ & $2.76 \mathrm{os}$ & 1677 & $14.16 \%$ & 1294 & $1496 \%$ & $49,37^{\circ}$ & -1.62 \\
\hline \multirow{3}{*}{$\begin{array}{l}\text { Recept- } \\
\text { ion }\end{array}$} & Success & 1411 & $9.13 \%$ & 1142 & $9.64 \%$ & $28.34^{\circ}$ & $-1,43$ & 1411 & $9.13 \%$ & 753 & $8.71 \%$ & $200.08^{8}$ & 1.1 & 1142 & $9.64 \%$ & 753 & $8.71 \%$ & $79.5^{\circ}$ & $2.28 *$ \\
\hline & Error & 76 & $0.49 \%$ & 77 & $0.65 \%$ & 0.01 & -1.74 & 76 & $0.49 \%$ & 90 & $1.04 \%$ & $1.18^{\circ}$ & ${ }_{4.94}$ & 77 & $0.65 \%$ & 90 & $1.04 \%$ & ${ }_{1.01}$ & ${ }_{3.07 * *}$ \\
\hline & Attempts & 699 & $4.52 \%$ & 586 & $4.95 \%$ & $9.94^{\circ}$ & -1.64 & 699 & $4.52 \%$ & 571 & $6.60 \%$ & $12.900^{\circ}$ & ${ }_{6.933}$ & 586 & $4.95 \%$ & ${ }_{571}$ & $6.60 \%$ & 0.19 & $5.07 \%$ \\
\hline \multicolumn{2}{|c|}{ Total I } & ${ }_{15452}$ & $100 \%$ & 11845 & $100 \%$ & $476.63^{\circ}$ & & 15452 & $100 \%$ & 8647 & $100 \%$ & $1921.5^{*}$ & & 11845 & $100 \%$ & 8647 & $100 \%$ & 499.,985 & \\
\hline
\end{tabular}

* Chi-Squar value $(0.05)=3.84$.

$* *$ significance of differences between the ratios $= \pm 1.96$.

DR \% Differences between ratios.

R Repetitions

$\mathrm{R} \%$ Ratios

Table (5) 
Significance differences between the Repetitions and significance of differences between the ratios for skills performance for the Teams of Level 1, 2, 3 at the London Olympics Games 2012 and Beijing Olympics Games 2008

\begin{tabular}{|c|c|c|c|c|c|c|c|c|c|c|c|c|c|c|c|c|c|c|c|}
\hline \multirow[t]{2}{*}{ Skills } & \multirow{2}{*}{$\begin{array}{l}\text { Skill } \\
\text { Perfor- } \\
\text { mance }\end{array}$} & \multicolumn{2}{|c|}{$\begin{array}{l}\text { London Olympics } \\
\text { Teams Level } 1\end{array}$} & \multicolumn{2}{|c|}{$\begin{array}{l}\text { Bejj̄ng Olympics } \\
\text { Teams Level I }\end{array}$} & \multirow{2}{*}{$\begin{array}{l}\text { Chi- } \\
\text { Squar }\end{array}$} & \multirow[t]{2}{*}{ DR \% } & \multicolumn{2}{|c|}{$\begin{array}{l}\text { London Olympics } \\
\text { Teams L.evel } 2\end{array}$} & \multicolumn{2}{|c|}{$\begin{array}{l}\text { Beijing Olympics } \\
\text { Teams Level } 2\end{array}$} & \multirow{2}{*}{$\begin{array}{l}\text { Chi- } \\
\text { Squar }\end{array}$} & \multirow[t]{2}{*}{$\mathrm{DR} \%$} & \multicolumn{2}{|c|}{$\begin{array}{l}\text { London Olympics } \\
\text { Teams Level } 3\end{array}$} & \multicolumn{2}{|c|}{$\begin{array}{l}\text { Beijing Olympics } \\
\text { Teams Level } 3\end{array}$} & \multirow{2}{*}{$\begin{array}{l}\text { Chi- } \\
\text { Squar }\end{array}$} & \multirow[t]{2}{*}{ DR \% } \\
\hline & & $\mathbf{R}$ & $\mathbf{R} \%$ & $\mathrm{R}$ & $\mathbf{R} \%$ & & & $\mathrm{~s}$ & $\mathrm{~s} \%$ & $\mathrm{~s}$ & $\mathrm{~s} \%$ & & & $\mathrm{~s}$ & $\mathrm{~s} \%$ & $\mathrm{~s}$ & $\mathrm{~s} \%$ & & \\
\hline \multirow{3}{*}{ Spike } & Success & 1484 & $10.82 \%$ & 1593 & $10.31 \%$ & $3.86^{*}$ & 1.41 & 1015 & $10.48 \%$ & 1199 & $10.12 \%$ & $15.29 *$ & 0.86 & 775 & $9.53 \%$ & 869 & $10.05 \%$ & $5.38^{\circ}$ & -1.14 \\
\hline & Error & 480 & $3.50 \%$ & 485 & $3.14 \%$ & 0.03 & 1.72 & 338 & $3.49 \%$ & 407 & $3.44 \%$ & $6.39 \%$ & 0.22 & 394 & $4.84 \%$ & 359 & $4.15 \%$ & 1.63 & $2.16^{* * *}$ \\
\hline & Attempts & 1097 & $8.00 \%$ & 1209 & $7.82 \%$ & $5.44^{*}$ & 0.55 & 773 & $7.98 \%$ & 979 & $8.27 \%$ & $24.22^{*}$ & -0.75 & 678 & $8.33 \%$ & 648 & $7.49 \%$ & 0.68 & 2.02 \\
\hline \multirow{3}{*}{ Block } & Success & 296 & $2.16 \%$ & 362 & $2.34 \%$ & $6.62^{*}$ & -1.06 & 211 & $2.18 \%$ & 220 & $1.86 \%$ & 0.19 & 1.68 & 154 & $1.89 \%$ & 130 & $1.50 \%$ & 2.03 & $1.96^{* 0 *}$ \\
\hline & Error & 562 & $4.19 \%$ & 603 & $3.90 \%$ & 1.44 & 0.85 & 441 & $4.55 \%$ & 435 & $3.67 \%$ & 0.04 & $3.26^{\circ *}$ & 272 & $3.34 \%$ & 324 & $3.75 \%$ & $4.54^{*}$ & -1.41 \\
\hline & Attempts & 529 & $3.86 \%$ & 777 & $5.03 \%$ & $47.09 *$ & $-4.83^{* *}$ & 379 & $3.91 \%$ & 532 & $4.49 \%$ & $25.70^{*}$ & $2.09 \% *$ & 295 & $3.63 \%$ & 371 & $4.29 \%$ & $8.67^{*}$ & $-2.22^{* * *}$ \\
\hline \multirow{3}{*}{ Serve } & Success & 173 & $1.26 \%$ & 142 & $0.92 \%$ & 3.05 & $2.82^{* * *}$ & 109 & $1.13 \%$ & 74 & $0.62 \%$ & $6.70^{*}$ & $3.98^{* * *}$ & 65 & $0.80 \%$ & 61 & $0.71 \%$ & 0.13 & 0.7 \\
\hline & Error & 461 & $3.36 \%$ & 440 & $2.85 \%$ & 0.49 & $2.53^{* * *}$ & 281 & $2.90 \%$ & 327 & $2.76 \%$ & 3.48 & 0.62 & 238 & $2.93 \%$ & 294 & $3.40 \%$ & $5.89^{\circ}$ & -1.75 \\
\hline & Attempts & 2023 & $14.75 \%$ & 2326 & $15.05 \%$ & $21.11^{*}$ & -0.73 & 1463 & $15.1 \%$ & 1708 & $14.42 \%$ & $18.93^{*}$ & 1.42 & 1091 & $13.4 \%$ & 1154 & $13.35 \%$ & 1.77 & 0.12 \\
\hline \multirow{3}{*}{ Dig } & Success & 971 & $7.08 \%$ & 1133 & $7.33 \%$ & $12.47^{*}$ & -0.84 & 652 & $6.73 \%$ & 850 & $7.18 \%$ & $26.10^{*}$ & -1.27 & 539 & $6.63 \%$ & 547 & $6.33 \%$ & 0.06 & 0.79 \\
\hline & Error & 326 & $2.38 \%$ & 693 & $4.48 \%$ & $132.18^{\circ}$ & - $-9.79 \%$ & 266 & $2.75 \%$ & 554 & $4.68 \%$ & $101.15^{*}$ & - & 232 & $2.85 \%$ & 446 & $5.16 \%$ & $67.55^{\circ}$ & ·.58*. \\
\hline & Attempts & 341 & $2.49 \%$ & 333 & $2.16 \%$ & 0.09 & 1.88 & 230 & $2.38 \%$ & 267 & $2.25 \%$ & 2.76 & 0.59 & 214 & $2.63 \%$ & 197 & $2.28 \%$ & 0.70 & 1.48 \\
\hline \multirow{3}{*}{ Set } & Success & 1390 & $10.13 \%$ & 1041 & $6.74 \%$ & $50.10^{*}$ & $10.47 \times$ & 954 & $9.85 \%$ & 788 & $6.65 \%$ & $15.82^{*}$ & $8.56^{\circ * *}$ & 734 & $9.02 \%$ & 514 & $5.94 \%$ & $38.78^{*}$ & $7.60^{\circ *}$ \\
\hline & Error & 33 & $0.24 \%$ & 16 & $0.10 \%$ & $5.89 *$ & $2.85^{* * *}$ & 16 & $0.17 \%$ & 23 & $0.19 \%$ & 1.26 & -0.5 & 33 & $0.41 \%$ & 25 & $0.29 \%$ & 1.10 & 1.29 \\
\hline & Attempts & 1512 & $11.02 \%$ & 2113 & $13.67 \%$ & $99.64^{*}$ & -6.85"* & 1076 & $11.1 \%$ & 1677 & $14.16 \%$ & $131.20^{\circ}$ & $6.66^{* *}$ & 1070 & $13.2 \%$ & 1294 & $14.96 \%$ & 21.23* & $3.37^{* * *}$ \\
\hline \multirow{3}{*}{ Recept- } & Success & 1298 & $9.46 \%$ & 1411 & $9.13 \%$ & $4.71^{*}$ & 0.97 & 957 & 9.8856 & 1142 & $9.64 \%$ & $16.31^{*}$ & 0.6 & 801 & $9.85 \%$ & 753 & $8.71 \%$ & 1.48 & $2.54^{* * *}$ \\
\hline & Error & 134 & $0.98 \%$ & 76 & $0.49 \%$ & $16.02^{*}$ & $4.89 \%$ & 108 & $1.12 \%$ & 77 & $0.65 \%$ & $5.20^{*}$ & $3.68^{\circ *}$ & 100 & $1.23 \%$ & 90 & $1.04 \%$ & 0.53 & 1.15 \\
\hline & Attempts & 607 & $4.43 \%$ & 699 & $4.52 \%$ & $6.48^{*}$ & -0.41 & 414 & $4.28 \%$ & 586 & $4.95 \%$ & $29.58^{*}$ & $2.33^{* *}$ & 450 & $5.53 \%$ & 571 & $6.60 \%$ & $14.34^{*}$ & $-2.9 .9 *$ \\
\hline \multicolumn{2}{|c|}{ Total Repetitions } & 13717 & $100 \%$ & 15452 & $100 \%$ & $103.2^{*}$ & & 9683 & $100 \%$ & 11845 & $100 \%$ & $217.12^{\circ}$ & & 8135 & $100 \%$ & 8647 & $100 \%$ & $15.62^{*}$ & \\
\hline
\end{tabular}

* Chi-Squar value $(0.05)=3.84$.

$* *$ significance of differences between the ratios $= \pm 1.96$.

DR \% Differences between ratios.

R Repetitions

$\mathrm{R} \%$ Ratios

Table (6) 
Effectiveness of skill performance in different team of levels in London and Beijing Olympic Games

\begin{tabular}{|c|c|c|c|c|c|c|c|c|}
\hline $\begin{array}{c}\text { Olympic } \\
\text { Games }\end{array}$ & Level & Spike & Block & Serve & Dig & Set & Reception & $\begin{array}{l}\text { Total's } \\
\text { Levels }\end{array}$ \\
\hline \multirow{4}{*}{$\begin{array}{c}\text { London } \\
\text { Olympic } \\
\text { Games } \\
2012\end{array}$} & $\begin{array}{c}\text { Level } \\
1\end{array}$ & 1.33 & 0.81 & 0.89 & 1.39 & 1.46 & 1.57 & 7.45 \\
\hline & $\begin{array}{c}\text { Level } \\
2\end{array}$ & 1.32 & 0.78 & 0.91 & 1.34 & 1.46 & 1.57 & 7.38 \\
\hline & $\begin{array}{c}\text { Level } \\
3\end{array}$ & 1.21 & 0.84 & 0.88 & 1.31 & 1.38 & 1.52 & 7.14 \\
\hline & Total & 1.29 & 0.81 & 0.89 & 1.35 & 1.43 & 1.55 & 7.32 \\
\hline \multirow{4}{*}{$\begin{array}{c}\text { Beijing } \\
\text { Olympic } \\
\text { Games } \\
200\end{array}$} & $\begin{array}{c}\text { Level } \\
1\end{array}$ & 1.34 & 0.86 & 0.90 & 1.20 & 1.32 & 1.61 & 7.23 \\
\hline & $\begin{array}{c}\text { Level } \\
2\end{array}$ & 1.31 & 0.82 & 0.88 & 1.18 & 1.31 & 1.59 & 7.09 \\
\hline & $\begin{array}{c}\text { Level } \\
3\end{array}$ & 1.27 & 0.76 & 0.85 & 1.08 & 1.27 & 1.47 & 6.7 \\
\hline & Total & 1.31 & 0.81 & 0.88 & 1.15 & 1.30 & 1.56 & 7.01 \\
\hline
\end{tabular}

Although the different skills have a different effect on the performance, their utilization in practice has to be considered in a way to respect the proportion of use of different skills in practice and to design "game-like situations".

Another aspect to consider for exercise design is the ratio of success and the ratio of error (table 5); in London Olympics Games I found the error of the skills was reduced in relation to the level of the teams. These differences are statistically significant in the performance of the Dig in the teams of level 1. Set success increases with level, and this increase is significant for level 1. In Beijing Olympics Games, the success of Block, Serve, Set, and Dig increases in relation to the level, and this increase is significant in the Block of level 1. The block is probably the most difficult skill in volleyball. According to Demerchant (1992), block is more a mental activity rather than a somatic one. When properly structured, it covers a 
ground region that forces opponent spikers to improvise (Demerchant, 1995). Block is also the "first line" of defense and as for the opponents it is considered a simultaneously defensive and offensive movement aiming to stop the opponent attack and many times to gain a point (George, 1992). Coleman supports that block constitutes the first important factor of success during a volleyball match, followed by the attack as the second factor. The key for a successful block is the simplification of its total movement by "reading" the all available elements such as the direction of the opponent spiker, a foreseeing ability that results through experience (George, 1992).

These results let us establish objectives to control player action in practices and competitions and design exercises with "game-like situations". But it is important that when we do it, we consider the coefficient of skill performance, the percentage of actions in the game and the ratio success - error, in addition to considering which skills are more important for the classification in competition. Also, we should not forget the cyclical character of volleyball (graph 1), because if we do not respect it we can lose the game for the continuous actions. The teams have to have a minimum level of these skills (table 6), and when you get it, you have to maintain these levels, controlling the ratio successerror (table 5) and dedicate time to improve the skills most related to success (table 6).

The complexity of peak performance provokes finding clear differences between teams classified between 1 st8th with the rest of the teams, but the differences between these teams which established what teams got the medals are more difficult to establish.

\section{Conclusions}

In general, we can establish the following conclusions:

a) London Olympics Games a different reality than Beijing Olympics Games with respect to performance of skills 
(coefficients, ratio success, and ratio error).

b) Each skill has their different and specific efficacy criterion. This has to be considered when we design practices and establish objectives in competition.

\section{References}

1- Beal, D. (1989). Basic Team System and Tactics. En FIVB (Ed.), Coaches Manual I (pp. 333-356). Lausanne. FIVB.

2- Bergeles N., K. Barzouka, N. Elissavet (2009) Performance of mens and femens setters and attackers on Olympic-level volleyball teams. Int. J. Perform. Analysis Sport, 9: 141-148.

3- Diaz, J. (1992). Volleyball. Team managment (2nd edition). Sevilla. Wanceulen.

4- Diaz, J. (1996). Analysis and meaning of the technical, tactical and competitive behavior of masculine volleyball in the Games of the XXV Olympiad in Barcelona, 1992. Dissertation, Seville University, Spain.

5- Hamdi Abdel Moneim Ahmed (1975). Effect of the serve on scoring in volleyball
Matches, Master.D. thesis, Faculty of physical education for boys in Cairo, Helwan University.

6- Ismail M. Hashem (2003) Analytic Study for Attack skills and it's Efficiency on Matches Results of volleyball according to The Law's Adjustment. unpublished Master.D. thesis, faculty of physical Education Monofia university.

\section{7- Khaled Ramadan} Mohammed Shahin (1995). The effect of using some basic skills on 5th setresults in volleyball, Master.D. thesis, Faculty of physical education for girls in Cairo, Helwan University.

8- Kenny B., Gregory, C. (2006). Volleyball: Steps to success. Campaign, IL: Human Kinetics.

9- Laios Yiannis, Kountouris Panagiotis, Aggelonidis Ioannis and Katsikadelli Alkinoi. (2004). A Comparative Study of the Effectiveness of the Greek National Men's Volleyball Team With Internationally Top-Ranked 
International journal of volleyball research, Volume 7, Number 1

10- Lobietti R., R. Di Michele, F. Mermi (2006) Relationships between performance parameters and final ranking in professional volleyball. In Proceedings of WCPAS 2006 Szombathely 24-28 August 2006, World Congress of the Society of Performance Analysis in Sport. 11- Miskin M., G. Fellingham, L. Florence (2010) Skill importance in women's volleyball. JQAS, 6, Article 5.DOI: 10.2202/15590410.1234.

12- Rodriguez-Ruiz D., M. Quiroga, J. Miralles, S. Sarmiento, Y. de Saa, J. Garcia-Manso (2011). Study of the technical and tactical variables determining set win or loss in top-level European men's volleyball. JQAS, 7, Article 7. DOI: 10.2202/15590410.1281.

\section{3- Zhang, R.(1996)}

Fundamental technical and tactical aspects of setter training. International Volleytech, 3, 20-25.
14- McGown, C. (1994). Science of coaching Volleyball. Europe: Human Kinetics.

15- Demerchant, R. (1992). Blocking in volleyball. Scholastic Coach, 2, 5-8.

16- Coleman, J.(1992) Some new thoughts about the evaluation of blocking.Coaching Volleyball Special edition, 10,12.

17- George, C. (1992). Blocking and how to read the hitter. Coaching Volleyball, 6, 8-10.

\section{8- Hamdi Abdel Moneim} Ahmed (1975). Effect of the serve on scoring in volleyball Matches, Master.D. thesis, Faculty of physical education for boys in Cairo, Helwan University. 